\title{
Heritage tourism and the preservation of historic architecture: the case of Savannah, Georgia
}

\author{
K. Winson-Geideman \\ Texas A\&M University, College Station, Texas
}

\begin{abstract}
Savannah, Georgia is an outstanding example of a city with well-preserved building stock and a successful tourist economy, a position that many other communities would like to replicate. The purpose of this research is to preliminarily explore the evidence that links historic preservation with increased tourism expenditure using statistics and data acquired from several sources. Results support the symbiotic relationship between historic preservation and tourist expenditures.

Keywords: historic preservation, heritage tourism, institutional growth, adaptive reuse, Savannah Georgia, Historic Savannah Foundation, Savannah College of Art and Design.
\end{abstract}

\section{Introduction}

The City of Savannah, located in the State of Georgia in the United States, holds several titles, including the oldest planned city in the US, the top tourist attraction in the state, and the location of the South's first public art museum, the Telfair Museum of Art. More importantly, a 1.1 square mile section of the city is the largest National Historic Landmark District (NHLD) in the country, the highest district level awarded by the US National Park Service. Savannah earned this title partly because of its unique, well preserved city plan and historic building stock. In addition to the NHLD, there are no fewer than seven other historic districts, each representing a different era with its own distinct style of architecture and development pattern.

While Savannah is truly a unique city, its recent economic success belies the fact that it once suffered from many of the same problems that affect older cities 
in the northeast and Midwest: a deteriorating downtown, job loss, and corresponding socioeconomic issues. Yet the city was fortunate to capitalize on two distinct but interrelated trends that helped fuel its renaissance: the focus on historic and cultural preservation by the Historic Savannah Foundation and the Savannah College of Art and Design and the growth of heritage tourism. The purpose of this study is to describe preliminary evidence regarding the relationship between historic preservation and heritage tourism using data acquired from the Savannah Convention and Visitors Bureau, the Chatham County Assessor, the Historic Savannah Foundation and Savannah College of Art and Design.

\section{Historic preservation in Savannah}

The state of Georgia was chartered in 1733 by the work James Oglethorpe, an explorer and visionary with close ties to King George II. Oglethorpe's noble quest to establish a colony was rooted in his first-hand knowledge of the atrocities that occurred in some of Britain's most notorious debtor's prisons; the place, he hoped, would become a refuge for debtors. He, along with 21 others, chartered Georgia with Savannah as its first city, but when the time came to choose the men and women who would establish the new colony, a sufficient number of non-debtors were found so none came from the prisons [1].

Today's preservation initiatives in Savannah are deeply rooted in a largely intact city plan first designed by Oglethorpe, who focused on creating an orderly, functional town consisting of 24 squares placed at regular, short distances across the landscape. With 22 of the original squares still intact, his plan is lauded as an example of outstanding engineering by scholars of contemporary urban planning (Figure 1). In recent years the city has actively sought to preserve the squares and surrounding structures, receiving a great deal of support from the local community, non-profit organizations and the private sector.

\subsection{Historic Savannah Foundation}

From its beginnings, preservation efforts in Savannah have largely been grassroots and citizen led. The undisputed advent of preservation began 1955 with a small group of women that recognized the historical significance of the Isaiah Davenport House and fought to save it from demolition. The group eventually organized, formalizing their alliance as the Historic Savannah Foundation (HSF).

In 1962 the HSF conducted a comprehensive architectural survey of the buildings in what is now the National Historic Landmark District, mapping and evaluating over 1100 structures. This information proved invaluable as the group lobbied both the government and other residents to preserve Savannah's unique characteristics. The group further expanded its role by establishing a revolving fund that selectively purchased and optioned properties; they were so successful, that in a very short time, only $\$ 38,000$ in seed money resulted in over $\$ 1$ million reinvestment in a 13-acre area. To date, the revolving fund has directly funded the acquisition or option of nearly 200 properties. The indirect effects on 


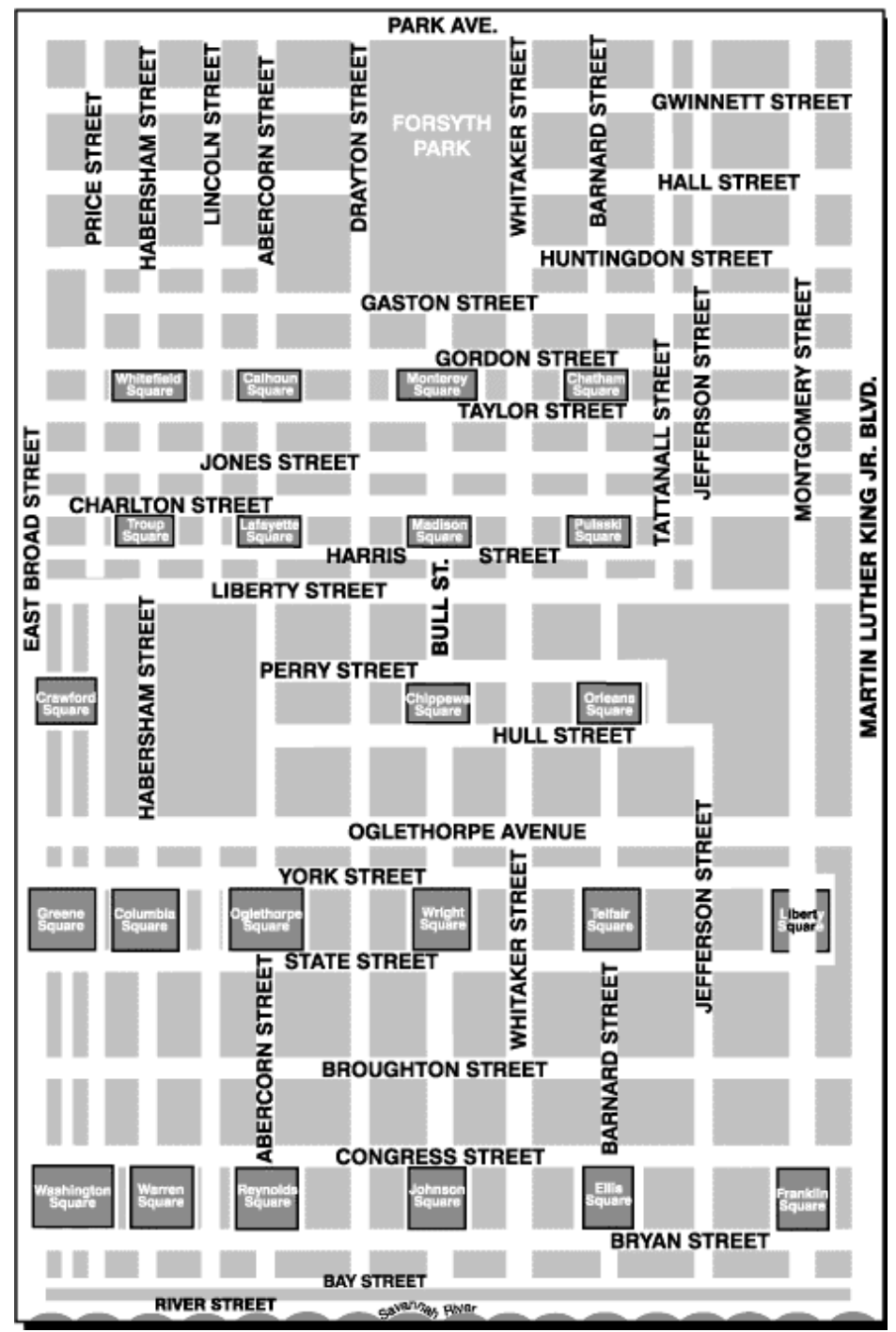

Figure 1: $\quad$ Map of Savannah, GA [2].

neighboring property preservation and value have yet to be calculated, but the multiplier is likely quite large.

Through the work of the HSF, the area comprising Oglethorpe's original city plan and an extended area received the National Historic Landmark District designation in 1966. The revolving fund is still the HSF's primary tool for preservation along with a preservation easement program [3]. 
Table 1 shows recent preservation activities by the foundation through the revolving loan fund. The fund is used by the foundation to acquire or option a property that it finds to be of significant historic value and in danger of being destroyed; a series of deed restrictions regarding the restoration of the property are recorded and ownership is transferred to a willing buyer with the expectation that it will be restored and preserved according to the restrictions.

Table 1: 2000-2006: Historic Savannah Foundation Revolving Fund activity.

\begin{tabular}{|c|c|c|c|c|}
\hline Year & $\begin{array}{c}\text { Properties } \\
\text { purchased }\end{array}$ & $\begin{array}{c}\text { Average } \\
\text { purchase price }\end{array}$ & $\begin{array}{c}\text { Average sale } \\
\text { price }\end{array}$ & $\begin{array}{c}\text { Average holding } \\
\text { period (days) }\end{array}$ \\
\hline \hline 2000 & 7 & $\$ 36,571$ & $\$ 39,868$ & 61 \\
\hline 2001 & 2 & $\$ 52,000$ & $\$ 55,000$ & 71 \\
\hline 2002 & 3 & $\$ 179,167$ & $\$ 148,167$ & 191 \\
\hline 2003 & 0 & 0 & 0 & 0 \\
\hline 2004 & 6 & $\$ 89,750$ & $\$ 92,167$ & 288 \\
\hline 2005 & 3 & $\$ 78,000$ & $\$ 86,667$ & 13 \\
\hline 2006 & 3 & $\$ 66,000$ & $\$ 76,500$ & 27 \\
\hline \hline Total & 24 & $\$ 81,217$ & $\$ 81,568$ & 144 \\
\hline
\end{tabular}

*Note that one property purchased in 2004 is still on the market. The average holding period less that property is 75.5 days.

While the Historic Savannah Foundation serves as the mother of the preservation movement in Savannah, another group has also become a key player: the Savannah College of Art and Design.

\subsection{The Savannah College of Art and Design}

In 1978 the Savannah College of Art and Design (SCAD) was legally incorporated and began its quest to become one of the leading design schools in the United States. Today it is the nation's largest private art school, with over 7,400 students and an operating budget of $\$ 180$ million. Enrollment has increased by over $40 \%$ since 2000 , and in 2003 SCAD's economic impact in the state of Georgia was $\$ 243$ million, according to the Georgia Foundation for Independent Colleges [4].

While the Historic Savannah Foundation and local residents deserve much of the credit for historic preservation, the Savannah College of Art and Design has contributed substantially to efforts in the city and is an economic catalyst in its own right with most of its facilities in or adjacent to the National Historic Landmark District. Approximately 2 million square feet of office and classroom space is occupied by SCAD. The college is unequivocally cited as the leader in adaptive re-use throughout the city, winning numerous awards from groups such as the Georgia Trust for Historic Preservation, the Art Deco Societies of America, the National Trust for Historic Preservation, the Victorian Society in 
America, and the American Institute of Architects. Four notable examples of SCAD's work in adaptive reuse and historic preservation are:

- Gordon Hall: Originally a nunnery for a Catholic church located on the same block, this 7,000-square-foot facility has been transformed into classroom and workspace for the fibers department. It was built in 1908 and acquired in 2003.

- Anderson Hall: Designed by Gottfried L. Norrman as a blend of Classical and Colonial Revival styles, this 20,478-square-foot, twostory ornate red brick building sits atop a stone/granite foundation and originally served as Anderson Street School. Built in 1896, it now houses the foundation studies program, a curriculum of introductory drawing and design courses required of students in all majors (purchased in 1988).

- Habersham Hall: Designed by Harry P. and Kenneth McDonald, the three-story, stucco Moorish Revival style Habersham Hall, with its distinctive onion-shaped dome, once served as the Chatham County jail. Comprised of 42,884 square feet and built in 1886, Habersham Hall houses the athletics department and was acquired in 1989.

- Eckburg Hall: Originally Henry Street School, Henry Hall was designed by William G. Preston and its construction was supervised by Gottfried L. Norrman. The three-story, 28,295-square-foot, red brick Queen Anne Revival style building features lavish terra cotta ornamentation, a gabled central pavilion, a monumental arched entrance and was built in 1892. Eckburg Hall houses the fashion department and was purchased in 1986 [5].

SCAD's growth and preservation efforts coupled with the work of the Historic Savannah Foundation are believed to have contributed exponentially to Savannah's economic engine, a $\$ 1$ billion tourism industry. Statistics show that tourism is a vital part of the local economy, with close links to a well-preserved built environment.

\section{Tourism in Savannah}

Heritage tourism has been cited as the fastest growing sector of the tourist economy in the United States [6]. While its links to the preservation of the built environment may be obvious, the "heritage industry" as it is often called, is actually segmented into three areas: cultural [7], natural [8], and built [9]. Cultural components include artifacts, such as items found in a museum that represent the history and culture of a people, place or time. These items often represent different things to different individuals. For instance, relics of the Civil War may stimulate different thoughts and emotions in a person of AfricanAmerican descent than they do in a person of Anglo descent. Natural resources focus on the ecological components of an area such as the Blue Ridge Mountains or the Great Salt Lake. The built environment focuses on man-made aspects, largely represented by the architecture and design of a certain building or area. 
The link between preserved historic sites and tourism is clearly shown in a Travel Industry Association of America (TIAA) survey of travelers. According to the report, in 1996 over one-fourth of US adults participated in a trip that visited an historic site or museum, and the average cost of that trip was $\$ 615$ (\$340 median) [10]. That same year heritage travelers in New Jersey spent about $\$ 433$ million, over three times the amount spent in historic rehabilitation in the state [11].

Savannah's tourist economy has grown steadily over the past several years. In 2004 over 6 million people visited the city - a growth of $6 \%$ over the previous year. Eighty percent of those trips were leisure rather than business with $30 \%$ visiting friends or relatives, and direct spending for leisure travel rose $8.4 \%$ in 2004 [12].

Direct tourism expenditures have increased an average of $7 \%$ annually between 1995 and 2005. Table 2 shows direct tourism expenditures in millions of US dollars and the corresponding change from the previous year. With the exceptions of the years 2001 and 2002, spending has grown steadily and is expected to continue increasing.

Table 2: $\quad$ 1995-2005: tourism expenditures, Savannah, GA [13].

\begin{tabular}{|c|c|c|}
\hline Year & $\begin{array}{c}\text { Tourism } \\
\text { expenditures } \\
\text { (\$ millions) }\end{array}$ & $\begin{array}{c}\text { Change from } \\
\text { previous year }\end{array}$ \\
\hline \hline 1995 & 660 & -- \\
\hline 1996 & 757 & $13 \%$ \\
\hline 1997 & 862 & $12 \%$ \\
\hline 1998 & 966 & $11 \%$ \\
\hline 1999 & 1,043 & $7 \%$ \\
\hline 2000 & 1,172 & $11 \%$ \\
\hline 2001 & 1,059 & $-11 \%$ \\
\hline 2002 & 1,032 & $-3 \%$ \\
\hline 2003 & 1,208 & $15 \%$ \\
\hline 2004 & 1,213 & $0 \%$ \\
\hline 2005 & 1,385 & $12 \%$ \\
\hline \hline Average & 1,032 & $7 \%$ \\
\hline
\end{tabular}

\section{Linking tourism and preservation in Savannah: preliminary evidence}

Evidence shows that the combined effect of SCADs and the HSF's preservation efforts as well as influx of tourism dollars have contributed to an improved market for the restoration and adaptive reuse of historic properties by the private sector. Using data collected from the Chatham County Assessor, a survey of 
1,199 residential properties built prior to 1940 and located in Savannah's National Historic Landmark District, Victorian and Thomas Square Historic Streetcar Districts shows that the effective age of properties at time of sale has increased steadily since 1995 (Table 3).

Effective age is defined as year of sale less the year the property was last renovated and is a much more appropriate measure of change than actual age. While actual age declines as the year of sale increases, effective age can vary based on changes in the local market. The importance of this statistic must not be underestimated because properties with a higher effective age require more maintenance resulting in additional expense for owners. This increase infers that, over time, a greater tolerance for the risks associated with older properties has developed within the Savannah housing market. A decreasing or stagnate effective age reflects a market adverse to the risk associated with an older housing stock.

Table 3: 1995-2004: transactions for properties built pre-1940, Savannah, GA.

\begin{tabular}{|c|c|c|c|c|c|}
\hline $\begin{array}{c}\text { Year of } \\
\text { Sale }\end{array}$ & $\begin{array}{c}\text { Number } \\
\text { of } \\
\text { Properties }\end{array}$ & $\begin{array}{c}\text { Year } \\
\text { Built* }\end{array}$ & $\begin{array}{c}\text { Actual } \\
\text { Building } \\
\text { Age* }\end{array}$ & $\begin{array}{c}\text { Effective } \\
\text { Year } \\
\text { Built* }\end{array}$ & $\begin{array}{c}\text { Effective } \\
\text { Age at Sale* }\end{array}$ \\
\hline \hline 1995 & 63 & 1883 & 123 & 1980 & 15 \\
\hline 1996 & 58 & 1893 & 113 & 1980 & 16 \\
\hline 1997 & 60 & 1888 & 118 & 1982 & 15 \\
\hline 1998 & 79 & 1895 & 111 & 1983 & 15 \\
\hline 1999 & 143 & 1893 & 113 & 1982 & 17 \\
\hline 2000 & 152 & 1896 & 110 & 1983 & 17 \\
\hline 2001 & 155 & 1870 & 110 & 1958 & 18 \\
\hline 2002 & 193 & 1891 & 115 & 1985 & 17 \\
\hline 2003 & 240 & 1893 & 113 & 1983 & 20 \\
\hline 2004 & 56 & 1859 & 111 & 1948 & 20 \\
\hline \hline Total & 1,199 & & & & \\
\hline
\end{tabular}

*Mean value

Labor statistics also reflect the symbiotic relationship between tourism and preservation. As one would expect, employment has been strengthened by increased tourist spending. The mean unemployment rate between 2000 and 2005 for the Savannah Metropolitan Statistical Area was 3.78\%, with no single year exceeding $4.1 \%$. This is in contrast to the national mean rate of $5.18 \%$ [14]. Between 2005 and 2006, the leisure and hospitality industry saw an increase in sector employment of $4.7 \%$ while the construction industry experienced a $4.4 \%$ increase [15].

Figure 2 graphically portrays the relationship between the effective age of historic properties at time of sale, direct tourism spending and unemployment. The tourism expenditure trend line closely reflects the effective age of buildings 
at time of sale, emphasizing the dependent relationship between preservation and tourist spending. The employment rate has an inverse relationship to the other variables. The links are clear: when tourism expenditures increase employment in the hospitality sector also increases. Further, as the effective age of buildings increases, so does the need for additional employees in the construction sector, assuming these properties are transacting for the purpose of preservation or adaptive reuse.

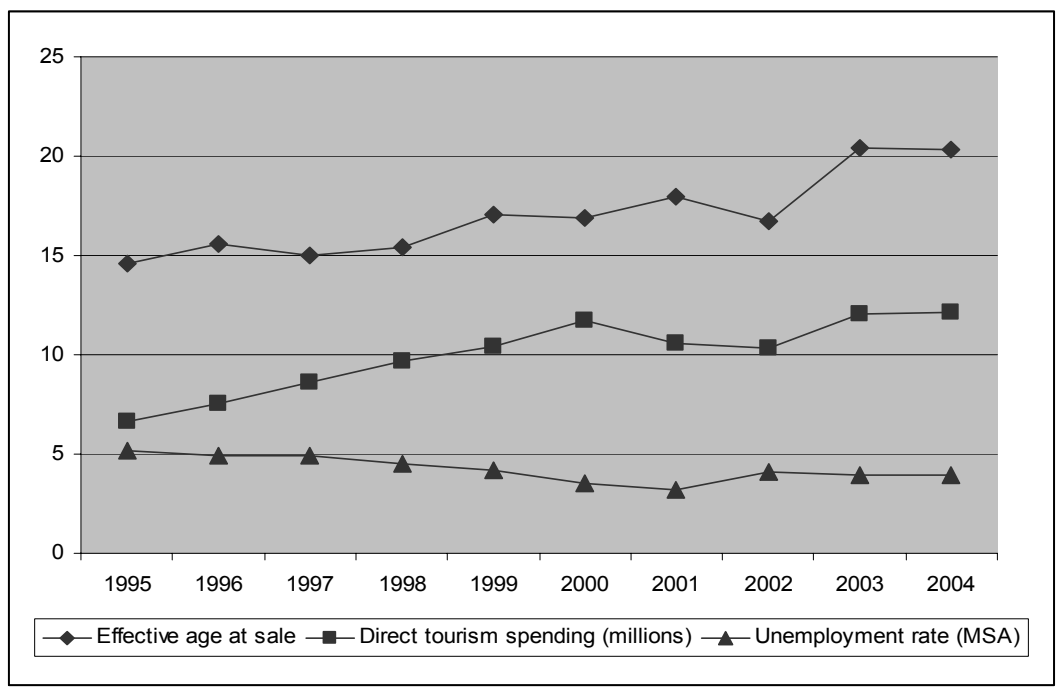

Figure 2: 1995-2004: change in property age, tourism spending and unemployment, Savannah, GA.

\section{Conclusion}

This research provides preliminary evidence that supports the dependent relationship between historic preservation and tourism spending in Savannah, Georgia. While some may suggest that the heritage tourism and historic preservation conundrum is the equivalent of the chicken and the egg, evidence shows that preservation initiatives serve as the mechanism that stimulates tourism which then produces additional preservation activity. Further research will explore these links using econometric models as well as descriptive methods.

Savannah is an exceptional example where historic preservation initiatives have been the catalyst for urban revitalization and increased tourist spending. The implication for others is that investing in historic preservation can result in increased tourist expenditures, the scale of which can be significant to the economy of communities that are able to convert the liability of age into an asset. Cities that are motivated to invest in downtown and neighborhood revitalization may have the opportunity to capitalize on an influx of tourism expenditures with increased investment resulting in increased property values and corresponding 
tax revenues. As private investment occurs, physical appearance improves and tourism expenditures continue to grow.

\section{References}

[1] http://ourgeorgiahistory.com/people/oglethorpe.html accessed on March $14,2007$.

[2] http://www.insiders.com/savannah/map-downtown.htm accessed on March 14, 2007.

[3] http://www.historicsavannahfoundation.org/AboutUs.aspcredit accessed on March 14, 2007.

[4] http://www.scad.edu/about/news/topstories/2005/111405.cfm accessed on December 31, 2005.

[5] www.scad.org accessed on August 27, 2006.

[6] Alzua, A., O’Leary, J. and Morrison, A. Cultural and Heritage Tourism: Identifying Niches for International Travelers. The Journal of Travel and Tourism Studies 9(2):2-13, 1998.

[7] Richards, G. Production and Consumption of European Cultural Tourism. Annals of Tourism Research 23:261-283, 1996.

[8] Hall, C. Tourism and the Establishment of National Parks in Australia. In Tourism and National Parks, R. Butler and S. Boyd, eds. Chichester: Wiley, pp. 29-38, 2000.

[9] Laws, E. Conceptualizing Visitor Satisfaction Management in Heritage Settings: An Exploratory Blueprinting Analysis of Leeds Castle, Kent. Tourism Management 19:545-554, 1998.

[10] Travel Industry Association of America. Profile of Travelers Who Participate in Historic and Cultural Activities. Results from the TravelScope E Survey, 1997.

[11] Listoken, D. and Lahr, M.L. Economic Impacts of Historic Preservation. Research prepared for the New Jersey Historic Trust, 1997.

[12] Savannah Area Chamber of Commerce 2006 Forecast and 2005 Economic Trends: p. 27, November 2005.

[13] Courtesy Savannah Travel \& Tourism, 2007.

[14] Bureau of Labor Statistics: http://www.bls.gov/cps/cpsaat1.pdf, accessed on March 18, 2007.

[15] Savannah Economic Development Authority, http://www.seda.org/ content.php?section=data\&subsection=business_climate\#employment, accessed on March 15, 2007. 